\title{
Nogo-66 Receptor at Cerebellar Cortical Glia Gap Junctions in the Rat
}

\author{
Xia Liu Ying-Ying Liu Wei-Lin Jin Hui-Ling Liu Gong Ju \\ Institute of Neurosciences, 4th Military Medical University, Xi'an, China
}

\section{Key Words}

Nogo · Nogo-66 receptor, rat - Glia - Gap junction • Cerebellum

\begin{abstract}
Nogo-A is a myelin inhibitor of neurite outgrowth that accounts for the difficulty in fiber regeneration in the central nervous system. Its 66-amino-acid extracellular domain (Nogo-66) contributes to the inhibitory activity of Nogo-A. The Nogo-66 receptor is widely distributed in neurons of the central nervous system, including the cerebellum. In our study on the distribution of Nogo-66 receptor in the cerebellar cortex in the rat, we unexpectedly found Nogo-66 receptor immunoreactivity in the glia cells, particularly abundant beneath the Purkinje cells. The presence of Nogo-66 receptor in glia cells has not been reported before. A detailed study was thus conducted. Immunoelectron microscopic investigation clearly demonstrated that the Nogo-66 receptor immunoreactivity could be ascertained at the gap junction between glia cells, indicating that the Nogo-66 receptor may modulate the communication between glia cells through gap junctions.
\end{abstract}

Copyright (C) 2005 S. Karger AG, Basel

\section{Introduction}

Nogo-A is a myelin inhibitor of neurite outgrowth that accounts for the difficulty in fiber regeneration in the central nervous system [1-3]. Its 66-amino-acid extracellular domain (Nogo-66) has been reported to be one of the major domains that underlie the inhibitory activity of Nogo-A [2, 4]. Nogo-A was first found in oligodendrocytes. Later, it was found to be widely expressed in central nervous system neurons as well [5-8], indicating that Nogo-A may have a diversity of functions [9]. The Nogo66 receptor $(\mathrm{NgR})$ has an ectodomain and a glycosylphosphatidylinositol anchorage site [4]. It is widely distributed in neurons of the central nervous system, including the cerebellum $[4,7,10,11]$. In our scrutiny for $\mathrm{NgR}$ immunoreactivity (irty) in the cerebellum, we found that it could be identified in the neuropil, particularly beneath the Purkinje cells. A detailed study was thus conducted to characterize the neuropil NgR-irty and found unexpectedly that the NgR-irty could be found in the glia cells, which had not been reported before. Moreover, immunoelectron microscopic study demonstrated that the NgRirty could be localized at the glial gap junctions, indicating that $\mathrm{NgR}$ may modulate the activity of the gap junction.

X.L. and Y.-Y.L. contributed equally to this work.

\begin{tabular}{ll}
\hline KARGER & () 2005 S. Karger AG, Basel \\
Fax +4161306 1234 & 1424-862X/05/0143-0096\$22.00/0 \\
$\begin{array}{l}\text { E-Mail karger@karger.ch } \\
\text { www.karger.com }\end{array}$ & $\begin{array}{l}\text { Accessible online at: } \\
\text { www.karger.com/nsg }\end{array}$
\end{tabular}


Fig. 1. NgR-irty in the cerebellar cortex. A Omission of primary antibody control. Differential interference contrast microscopy to bring out the structural background. No staining could be detected above a very faint background. B Note the relatively weak $\mathrm{NgR}$-irty in the molecular layer (m) and the strong NgR-irty in Purkinje cell layer (p) and granule layer (g), particularly next to the Purkinje layer (see $\mathbf{A}$ ). There is often a clear space surrounding the NgR-immunoreactive Purkinje cell which is shown in figure $3 \mathrm{~A}$ to be occupied by astrocytic processes. Thus, the NgR-irty is distributed on the periphery and in the cytoplasm of the Purkinje cells. Bars $=25 \mu \mathrm{m}$.
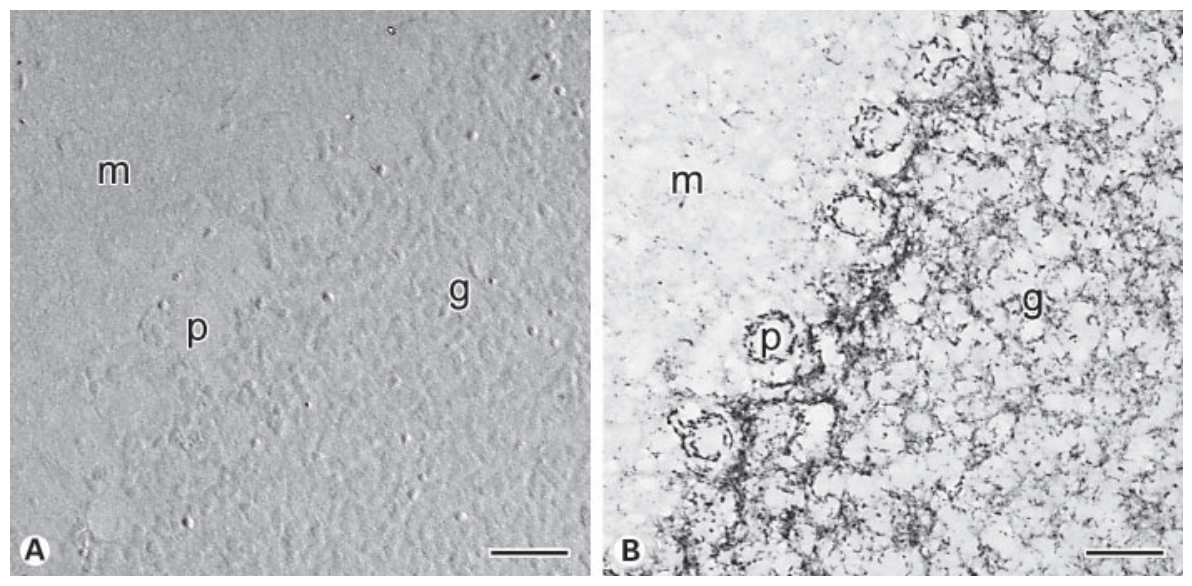

\section{Materials and Methods}

Male adult Sprague-Dawley rats (weighing 250-280 g) were used. For light microscopic immunohistochemistry, the rat was deeply anesthetized with $1 \%$ sodium pentobarbital $(50 \mathrm{mg} / \mathrm{kg}$ i.p. $)$ and perfusion fixed with $0.9 \%$ saline followed by ice-cold $4 \%$ paraformaldehyde in $0.1 \mathrm{M}$ phosphate buffer ( $\mathrm{pH} 7.4$ ). The cerebellum was removed and cryoprotected in successive 20 and 25\% sucrose at $4{ }^{\circ} \mathrm{C}$ for $24 \mathrm{~h}$ each. Sections $(8 \mu \mathrm{m})$ were cut on a cryostat. The sections were treated for $1 \mathrm{~h}$ in phosphate-buffered saline (PBS) containing $5 \%$ bovine serum albumin, $5 \%$ normal goat serum, and $0.3 \%$ Triton $\mathrm{X}-100$ and incubated overnight at $4{ }^{\circ} \mathrm{C}$ with the rabbit antibody against NgR (1:300; Alpha Diagnostic International, San Antonio, Tex., USA). The antibody recognizes 17 amino acids near the $\mathrm{C}$ terminus of $\mathrm{NgR}$. The sections were incubated in biotinylated antirabbit IgG (1:400; Sigma Chemical, St. Louis, Mo., USA) at room temperature for $2 \mathrm{~h}$ and visualized by means of the glucose oxidase-DAB-nickel method [12]. For double immunostaining, the sections were incubated in a cocktail of anti-NgR (1:400) and the monoclonal antibody against the astrocyte marker GFAP $(1: 1,000$; Sigma) or against the oligodendrocyte marker RIP (1:600; Chemicon International, Temecula, Calif., USA). A mixture of Alexa Fluor 488 conjugated goat antirabbit IgG (for NgR, 1:400; Molecular Probes, Eugene, Oreg., USA) and Texas Red conjugated goat antimouse IgG (for GFAP or RIP, 1:800; Molecular Probes) was used as secondary antibodies. An FV300 laser scanning microscope (Olympus, Tokyo, Japan) was used for confocal examinations. Omission of the primary antibodies served as negative controls.

Western blotting was performed for checking the specificity of the anti-NgR. The rat was decapitated, and the head was immediately put on ice. Cerebellum and cerebral cortex were carefully dissected out and immediately frozen in liquid nitrogen. They were then kept at $-70^{\circ} \mathrm{C}$ before use. For protein extraction, each sample was homogenized on ice in RIPA buffer (Tris- $\mathrm{HCl} 50 \mathrm{mM}$, pH 7.5, $\mathrm{NaCl} 150 \mathrm{~m} M$, NP-40 1\%, sodium deoxycholate $0.5 \%$, SDS $0.1 \%$, and complete protease inhibitor cocktail added at a volume ratio 1:50) and centrifuged at 13,000 $\mathrm{g}$ at $4^{\circ} \mathrm{C}$. Samples from the supernatant were loaded on 10\% SDS-PAGE. The proteins were electrotransferred to a polyvinylidene difluoride membrane and reacted with anti-NgR $(1: 1,000)$ and antirabbit IgG-POD $(1: 12,500)$ and chemiluminescent solution (chemilumiescence Western blotting kit; Boehringer Mannheim, Mannheim, Germany). Western blotting was performed according to the kit protocol.

For immunoelectron microscopy, the rats were perfusion fixed with a mixture of $4 \%$ paraformaldehyde, $0.05 \%$ glutaraldehyde, and $15 \%(\mathrm{v} / \mathrm{v})$ saturated picric acid in $0.1 \mathrm{M}$ phosphate buffer $(\mathrm{pH}$ 7.4) for $30 \mathrm{~min}$. The cerebellum was removed and postfixed in the same fixative for $3 \mathrm{~h}$ at $4^{\circ} \mathrm{C}$. Tissue sections of $50 \mu \mathrm{m}$ were prepared with a vibratome and placed into $0.01 M$ PBS (pH 7.4) containing $25 \%$ sucrose and $10 \%(\mathrm{v} / \mathrm{v})$ glycerol for $1 \mathrm{~h}$ for cryoprotection. After being subjected to a freeze-thaw treatment, the sections were immersed in $0.01 \mathrm{M}$ PBS containing 5\% bovine serum albumin and $5 \%$ normal goat serum for $4 \mathrm{~h}$ to block nonspecific immunoreactivity. The sections were incubated with anti-NgR (1:300) for $48 \mathrm{~h}$ at $4^{\circ} \mathrm{C}$, rinsed in $0.01 \mathrm{MPBS}$, and incubated with biotinylated goat antirabbit IgG (1:200, Sigma) followed by goat antirabbit IgG conjugated to 1.4-nm gold particles (1:100; Nanoprobes, Stony Brook, N.Y., USA) at room temperature overnight. After rinsing, the sections were postfixed with $2 \%$ glutaraldehyde in $0.01 M$ PBS for $45 \mathrm{~min}$. Silver enhancement was performed in the dark with a HQ Silver kit (Nanoprobes). Before and after the silver enhancement, the sections were rinsed with deionized water several times. The sections were further fixed with $0.5 \%$ osmium tetroxide in $0.1 \mathrm{M}$ phosphate buffer for $1 \mathrm{~h}$, dehydrated with graded ethanol, replaced with propylene oxide, and flat embedded in Epon 812. The NgRimmunoreactive areas of the Purkinje and granular layers of the cerebellar cortex were selected and trimmed under a stereomicroscope and mounted onto blank resin stubs. Ultrathin sections were prepared on an LKB Nova Ultratome (LKB Instruments, Bromma, Sweden) for observation under a JEM-1230 electron microscope (JEOL, Tokyo, Japan) after being counterstained with uranyl acetate and lead citrate.

\section{Results}

\section{Light Microscopic Study}

The primary antibody omission controls showed no labeling above background (fig. 1A). Western blot of both cerebral cortex and cerebellum showed a single band at 
$\sim 85 \mathrm{kDa}$, corresponding to the molecular weight of $\mathrm{NgR}$ (fig. 2).

Light microscopic immunohistochemistry displayed fine granular $\mathrm{NgR}$-irty in all three layers of the cerebellar cortex: in the molecular layer it appeared as sparely scattered fine granules, often lining radially, presumably along the paths of the Purkinje dendritic shafts and/or the Bergmann glia; in the Purkinje cell layer, there was a clear space surrounding each circular or spherical $\mathrm{NgR}$-irty of the Purkinje cells; the granular cell layer showed strongest NgR-irty, densest next to the Purkinje cell layer (fig. 1B). It is clear from the confocal image that the space surrounding the Purkinje cells was occupied by astrocytic processes (fig. 3A). Thus, the NgR-irty in the Purkinje cell layer is distributed on the periphery and in the cytoplasm of the Purkinje cells.

Double immunostaining and confocal microscopic analysis showed that the NgR-irty occurred at either the GFAP-immunoreactive astrocytic or the RIP-immunoreactive oligodendrocytic processes (fig. 3).

\section{Electron Microscopic Study}

Very unexpectedly, under the electron microscope, $\mathrm{NgR}$-irty could be identified at gap junctions which may imply a hitherto unknown functional aspect of the $\mathrm{NgR}$. We, therefore, focused our ultrastructural study on the gap junction. Typically layered gap junction profiles were frequently found between glia cells. NgR-irty could be identified at gap junctions between glia cells, either between astrocyte and oligodendrocyte (fig. 4), or between astrocytes (fig. 4C). The layered profile extended for longer or shorter stretches. Clusters of silver-enhanced immunogold particles occurred predominantly along the cytoplasmic surface of the junction, seldom any could be identified in the gap. At their ends of the layered profile, the contacting cell membranes either diverged or often blurred out due to tilting of the section plane, where immunoparticles were frequently observed (fig. 4B).

\section{Discussion}

The results of the Western blot supported the specificity of the antibody we used. The $\mathrm{NgR}$ is anchored to the lipid raft of the cell membrane by glycosylphosphatidylinositol and is exposed to the outer surface of the membrane. In the gap junction, the $\mathrm{NgR}$ is located in the gap between the counterparts forming the junction. In the present study, however, seldom any silver-enhanced immunogold particles could be ascertained in the gap. Ap-

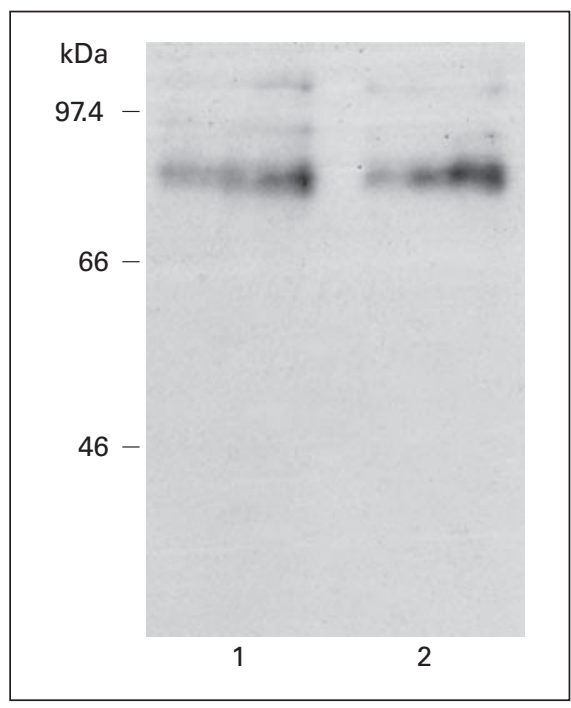

Fig. 2. Western blots. Lane 1: cerebral cortex which is known to have plenty of $\mathrm{NgR}$ and was used here as a positive control. Lane 2: cerebellum. In both lanes, there is a single band at $\sim 85 \mathrm{kDa}$, corresponding to the molecular weight of $\mathrm{NgR}$.

parently, this is due to the fact that the gap between the apposing membranes of the junction measures only 2$3 \mathrm{~nm}$, much too narrow for IgG molecules to squeeze into [for the size of IgG, see 13]. Furthermore, the gap is tightly packed with connexin channels joining the two sides which further impede passing of immunoreagents into the gap. The layered profile of the gap junction can be seen only, if it is cut perpendicular to its plane. Tilting of the cutting angle will result in blurring out of the layers, meanwhile exposing the outer surface of the apposing membranes and the $\mathrm{NgRs}$ anchored on them, rendering them available for immunohistochemical reagents. Thus, in the present study, the immunogold particles were often seen in clusters at the blurred part of the gap junction

Fig. 3. Confocal microscopy of the cerebellar cortex. NgR-irty, green; GFAP-irty and RIP-irty, red. A NgR-/GFAP-irties. In the molecular layer, the $\mathrm{NgR}$-irty often appears as radiating processes. In the Purkinje cells, the NgR-irty appears on the periphery and in the cytoplasm. The cells bodies are surrounded by astrocytic processes. Colocalization of a number of the NgR-irty dots with astrocytic processes can be seen; the arrows point to some of them as examples. The inset is a blowup of the boxed area to show more clearly the colocalization. B NgR-/RIP-irties. The arrows point to some of the colocalized NgR-/RIP-irties. The inset is a blowup of the boxed area. The thickness of the confocal optic section is $0.173 \mu \mathrm{m}$. Bars $=50 \mu \mathrm{m}$; inset bars $=25 \mu \mathrm{m}$. 

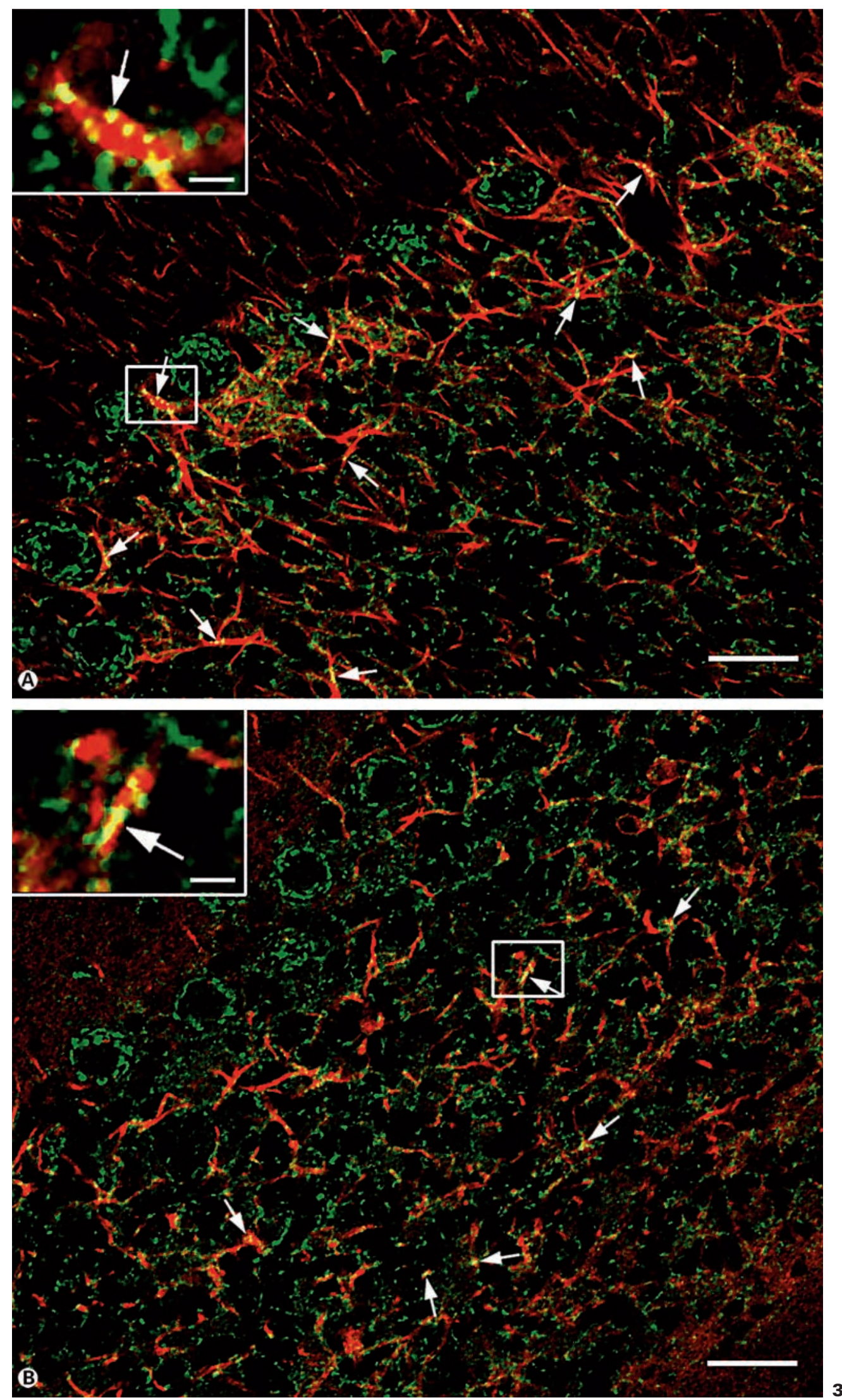

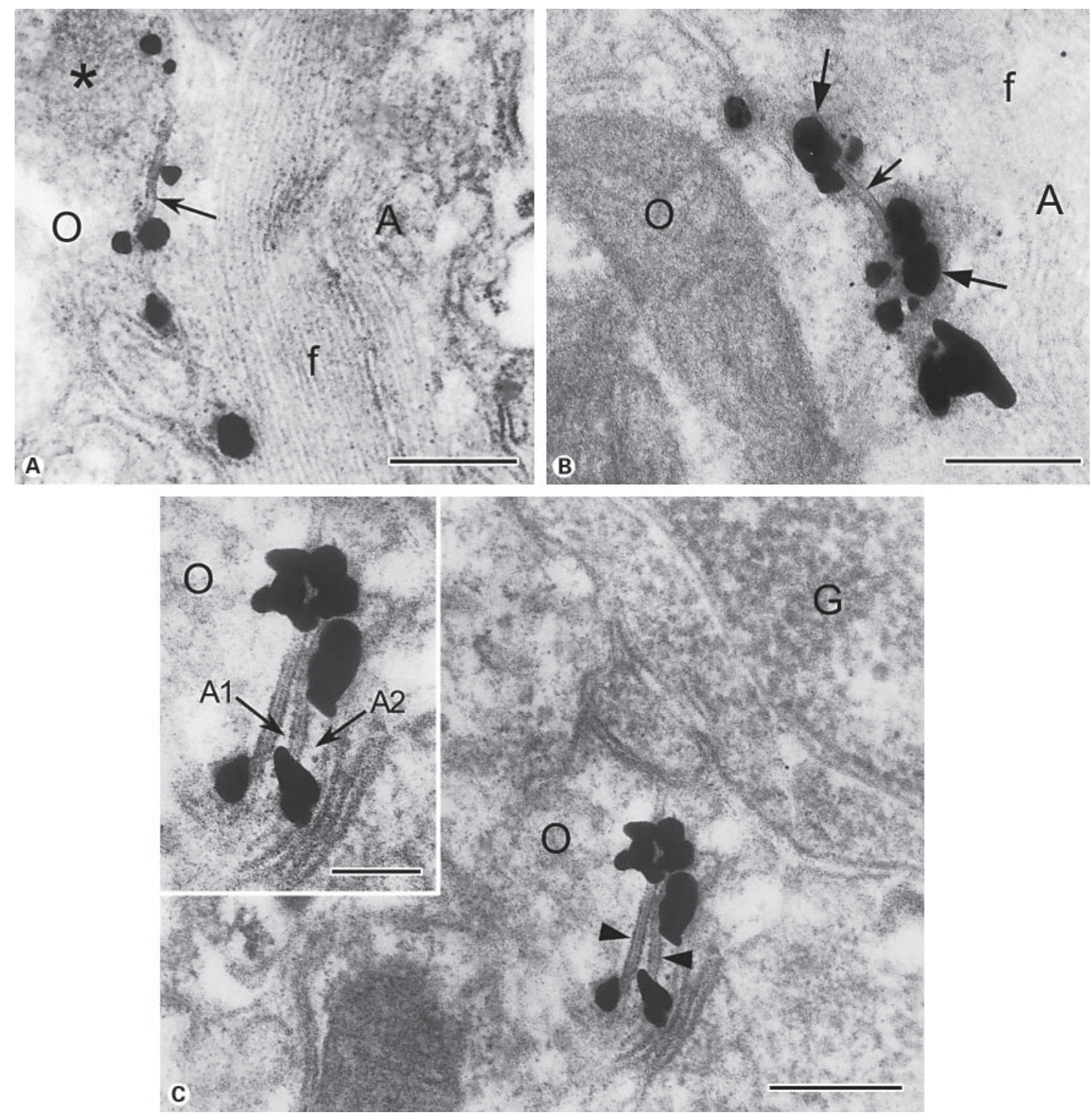

Fig. 4. Ultrastructural localization of NgR-irty. A Gap junction (arrow) between an astrocyte (A), which is characterized by the presence of compact bundles of glial filaments (f), and an oligodendrocyte $(\mathrm{O})$. The asterisk shows the cross section of a bundle of microtubules. Abundance of microtubules is one of the characteristics for identifying oligodendrocyte [25, p. 298]. Silver-enhanced gold particles can be seen along both sides of the gap junction. B Gap junction (small arrow) between an astrocyte (A) and an oligodendrocyte $(\mathrm{O})$. The large arrows point to the blurred ends of the gap junction with clusters of $\mathrm{NgR}$-immunoreactive immunogold

profiles. The appearance of immunogold particles at the cytoplasmic side of the gap junctions occurred, apparently, because the cell membrane was made permeable to immunoreagents by freeze-thaw treatment for preembedding immunoelectron microscopy and because the epi- particles. $\mathrm{f}=$ Glial filaments. C Two layered profiles of a gap junction can be seen (arrowheads). At their blurred ends, clusters of gold particles are evident. $\mathrm{G}=$ Nucleus of a neuron of the granular layer; $\mathrm{O}=$ Oligodendrocyte. The inset shows the detail of the gap junctions. A1 and A2 are two veil-like astrocytic extensions, the velate astrocytes [25, p. 282]. A1 forms the junction between the astrocyte and an oligodendrocyte $(\mathrm{O})$ with many microtubules; $\mathrm{A} 2$ forms the junction between two astrocytes. Bars in $\mathbf{A}-\mathbf{C}=200 \mathrm{~nm}$; the bar in the inset of $\mathbf{C}=100 \mathrm{~nm}$.

tope the antibody recognizes is close to the anchoring site of the $\mathrm{NgR}$ on the membrane.

The gap junction has been recently found to be functionally adjustable [14-21]. It can be adjusted by phosphorylation of connexins $[15,16,18,19]$, and a blocker 
has been found for opening and closing of hemichannels $[20,21]$. The presence of $\mathrm{NgR}$ at the gap junction suggests that it may play a role in modulating the function of the gap junction. The signal transduction pathways of $\mathrm{NgR}$ have not been fully elucidated. The NgR-p75NTR receptor complex activates Rho which eventually results in inhibition of axonal growth; in addition, activation of the NgR-p75NTR receptor complex also activates $G_{i}$ protein which prevents an increase in cAMP through inhibition of adenylate cyclase [22], and it has been reported that activation of cAMP-dependent protein kinase can lead to a rapid augmentation in connexin 43 phosphorylation, resulting in an increase in the intercellular communication through the gap junction $[23,24]$. Thus, there is at least one possible link between the signal transduction path- way of the $\mathrm{NgR}$ and the functional modulation of the gap junction.

This paper is the first report on the presence of $\mathrm{NgR}$ in glia cells and at their gap junctions. The functional significance of $\mathrm{NgR}$ at gap junctions is certainly a very interesting and important issue to be elucidated.

\section{Acknowledgments}

This work was supported by the Natural Sciences Foundation of China (Grant No. NSFC 30218003) and the Chinese National Key Project for Basic Research (Grant No. 2003CB515301). The technical assistance by Ms. Y.H. Lin and X.Y. Jaio is highly appreciated.

\section{References}

1 Chen MS, Huber AB, van der Haar ME, Frank M, Schnell L, Spillmann AA, Christ F, Schwab ME: Nogo-A is a myelin-associated neurite outgrowth inhibitor and an antigen for monoclonal antibody IN-1. Nature 2000;403:434439.

- 2 GrandPre T, Nakamura F, Vartanian T, Strittmatter SM: Identification of the Nogo inhibitor of axon regeneration as a Reticulon protein. Nature 2000;403:439-444.

-3 Prinjha R, Moore SE, Vinson M, Blake S, Morrow R, Christie G, Michalovich D, Simmons DL, Walsh FS: Inhibitor of neurite outgrowth in humans. Nature 2000;403:383-384.

-4 Fournier AE, GrandPre T, Strittmatter SM: Identification of a receptor mediating Nogo-66 inhibition of axonal regeneration. Nature 2001;409:341-346.

-5 Josephson A, Widenfalk J, Widmer HW, Olson L, Spenger C: NOGO mRNA expression in adult and fetal human and rat nervous tissue and in weight drop injury. Exp Neurol 2001; 169:319-328

-6 Huber AB, Weinmann O, Brosamle C, Oertle T, Schwab ME: Patterns of Nogo mRNA and protein expression in the developing and adult rat and after CNS lesions. J Neurosci 2002;22: 3553-3567.

7 Wang X, Chun SJ, Treloar H, Vartanian T, Greer CA, Strittmatter SM: Localization of Nogo-A and Nogo-66 receptor proteins at sites of axon-myelin and synaptic contact. J Neurosci 2002;22:5505-5515.

8 Hunt D, Coffin RS, Anderson PN: The Nogo receptor, its ligands and axonal regeneration in the spinal cord: A review. J Neurocytol 2002; 31:93-120.

-9 Jin WL, Liu YY, Liu HL, Yang H, Wang Y, Jiao XY, Ju G: Intraneuronal localization of Nogo-A in the rat. J Comp Neurol 2003;458: $1-10$.
10 Josephson A, Trifunovski A, Widmer HR, Widenfalk J, Olson L, Spenger C: Nogo-receptor gene activity: Cellular localization and developmental regulation of mRNA in mice and humans. J Comp Neurol 2002; 453:292-304.

-11 Hunt D, Mason MR, Campbell G, Coffin R, Anderson PN: Nogo receptor mRNA expression in intact and regenerating CNS neurons. Mol Cell Neurosci 2002; 20:537-552.

12 Shu SY, Ju G, Fan LZ: The glucose oxidaseDAB-nickel method in peroxidase histochemistry of the nervous system. Neurosci Lett 1988;85:169-171.

13 Boehm MK, Woof JM, Kerr MA, Perkins SJ: The Fab and $\mathrm{Fc}$ fragments of IgA1 exhibit a different arrangement from that in IgG: A study by X-ray and neutron solution scattering and homology modelling. J Mol Biol 1999;286: 1421-1447.

14 Asamoto M, Oyamada M, el Aoumari A, Gros D, Yamasaki H: Molecular mechanisms of TPA-mediated inhibition of gap-junctional intercellular communication: Evidence for action on the assembly or function but not the expression of connexin 43 in rat liver epithelial cells. Mol Carcinog 1991;4:322-327.

- 15 Elvira M, Diez JA, Wang KK, Villalobo A Phosphorylation of connexin- 32 by protein kinase $\mathrm{C}$ prevents its proteolysis by mu-calpain and m-calpain. J Biol Chem 1993;268:1429414300.

16 Hossain MZ, Ao P, Boynton AL: Platelet-derived growth factor-induced disruption of gap junctional communication and phosphorylation of connexin- 43 involves protein kinase $\mathrm{C}$ and mitogen-activated protein kinase. J Cell Physiol 1998;176:332-341.
17 Lampe PD: Analyzing phorbol ester effects on gap junctional communication: A dramatic inhibition of assembly. J Cell Biol 1994;127(6 Pt 2):1895-1905.

18 Moreno AP, Fishman GI, Spray DC: Phosphorylation shifts unitary conductance and modifies voltage dependent kinetics of human connexin43 gap junction channels. Biophys J 1992;62:51-53.

19 Swenson KI, Piwnica-Worms H, McNamee H, Paul DL: Tyrosine phosphorylation of the gap junction protein connexin 43 is required for the pp60v-src-induced inhibition of communication. Cell Regul 1990;1:989-1002.

20 Plotkin LI, Manolagas SC, Bellido T: Transduction of cell survival signals by connexin-43 hemichannels. J Biol Chem 2002;277:86488657.

-21 Lampe PD, TenBroek EM, Burt JM, Kurata WE, Johnson RG, Lau AF: Phosphorylation of connexin 43 on serine 368 by protein kinase $\mathrm{C}$ regulates gap junctional communication. J Cell Biol 2000;149:1503-1512.

22 Igarashi M, Strittmatter SM, Vartanian T, Fishman MC: Mediation by G proteins of signals that cause collapse of growth cones. Science 1993;259:77-79.

23 Burt JM, Spray DC: Inotropic agents modulate gap junctional conductance between cardiac myocytes. Am J Physiol 1988;254(6 Pt 2): H1206-H1210.

24 Godwin AJ, Green LM, Walsh MP, McDonald JR, Walsh DA, Fletcher WH: In situ regulation of cell-cell communication by the cAMP-dependent protein kinase and protein kinase $\mathrm{C}$. Mol Cell Biochem 1993;127-128:293-307.

25 Peters A, Palay SF, Webster HdeF: The Fine Structure of the Nervous System: Neurons and Their Supporting Cells, ed 3. New York, Oxford University Press, 1991. 